\title{
Biopolietileno Baseado no Etanol
}

O produto compreende uma família de polietilenos produzidos a partir do monômero de etileno obtido através da desidratação do etanol baseado na cana-de-açúcar. A primeira resina a ser produzida em escala piloto foi um polietileno de alta densidade (PEAD), e depois disso foi produzido um polietileno linear de baixa densidade a partir do comonômero de buteno de fonte renovável. Ambos os produtos foram certificados de acordo com ASTM D 6866, que determinou que o carbono contido na amostra era $100 \%$ de fonte renovável, sem nenhum carbono de fonte fóssil.

Como parte da estratégia de desenvolvimento de mercado, o etileno de fonte renovável, produzido em uma planta piloto, está sendo polimerizado para a produção de alguns grades de polietileno do portfólio de polímeros da Braskem, incluindo resinas de alta densidade, e lineares de baixa densidade, feitos inteiramente a partir de materiais renováveis. A versatilidade desse biopolímero é demonstrada pela ampla variedade de propriedades para aplicações rígidas e flexíveis permitindo que o Polietileno Verde da Braskem seja usado na fabricação de sacolas, sacos plásticos, peças automotivas, brinquedos e embalagens para alimentos, cosméticos e produtos de higiene pessoal. Está em construção uma unidade industrial de 200.000 toneladas por ano com início de operação prevista para o último trimestre de 2010.

A lavoura de cana-de-açúcar captura o dióxido de carbono da atmosfera e o metaboliza para produzir açúcar a ser fermentado para gerar etanol. A tecnologia proprietária de alto rendimento usada para obter o monômero de etileno através da desidratação do etanol é muito simples e consiste em um passo de reação catalítica e uma sessão de purificação. O comonômero do buteno é produzido através do mesmo processo, usando biobutanol como matéria prima. Esse etileno é usado para produzir Polietileno Verde nas mesmas plantas de polimerização tradicionais. Esse polímero pode ser transformado em muitos tipos diferentes de produtos finais, usando as mesmas máquinas que já existem nas indústrias de processamento de produtos plásticos.

Após o final de sua vida útil, os produtos plásticos podem ser reutilizados com grande vantagem (porque são duráveis), reciclados (devido à estabilidade do polietileno) ou enviados para sistemas de reciclagem energética (devido à sua alta energia de combustão) - com a principal vantagem de gerar emissão neutra de carbono porque o $\mathrm{CO}_{2}$ liberado veio originalmente da atmosfera e será novamente capturado pela cana-de-açúcar na próxima safra.

A Avaliação de Ciclo de Vida para todo o ciclo de produção do polietileno verde indica a captura de 2.5 toneladas de $\mathrm{CO}_{2}$ por tonelada de polímero, ao invés das 2.5 toneladas de $\mathrm{CO}_{2}$ liberadas por um polietileno produzido a partir de matérias-primas fósseis, como a Nafta Petroquímica. Essa capacidade de reduzir os níveis de carbono da atmosfera é maior do que qualquer outro polímero e é consequência de três principais características:

- A alta produtividade da cana-de-açúcar para gerar biomassa que é utilizada como matéria-prima e fonte de energia.

- A eficiência do etanol baseado na cana-de-açúcar, que produz energia de fonte renovável 9 vezes superior à energia fóssil usada como insumo.

- A alta capacidade da molécula de polietileno de armazenar carbono (86\% por peso) se comparada a outras resinas de base biológica.

Uma outra vantagem da tecnologia é que ela produz apenas água e uma pequena quantidade de componentes oxigenados como subprodutos. $\mathrm{O}$ efluente aquoso pode ser facilmente tratado para gerar cerca de 0.65 toneladas de água de processo por tonelada de etileno, que podem ser recicladas em outros passos do processo, tais como na extração do caldo de cana-de-açúcar. Como consequência do alto rendimento da desidratação, do uso sinérgico dos fluxos de subprodutos e da possibilidade de usar as plantas e equipamentos de polimerização já existentes, o biopolietileno tem também um custo muito competitivo se comparado a outras resinas.

Para assegurar a liderança em polímeros verdes, de fonte renovável e seu compromisso com a inovação tecnológica e a sustentabilidade, a Braskem anunciou em setembro de 2008 a produção e certificação de amostra do $1^{\circ}$ Polipropileno $100 \%$ produzido a partir de fontes renováveis. Ainda na fase de pesquisas tecnológicas, a amostra de polipropileno verde baseado na cana-de-açúcar foi produzida em escala piloto no Centro de Tecnologia e Inovação Braskem, localizado na cidade de Triunfo, no Rio Grande do Sul. Porém, a rota tecnológica ainda precisa ser mais desenvolvida. Ainda não há uma data programada para que o PP verde chegue ao mercado. 